\title{
Phytoextraction by harvesting dead leaves: Cadmium accumulation associated with the leaf senescence in Festuca arundinacea
}

\section{Ling Fei}

Shanghai Jiao Tong University

\section{ShaoFan Zuo}

Shanghai Jiao Tong University

JiaXin Zhang

Shanghai Jiao Tong University

ZhaoLong Wang ( $\nabla$ turf@sjtu.edu.cn )

Shanghai Jiao Tong University https://orcid.org/0000-0001-5843-8687

\section{Research Article}

Keywords: Phytoextraction, Cadmium, Tall fescue, Leaf, Senescence

Posted Date: August 20th, 2021

DOI: https://doi.org/10.21203/rs.3.rs-760936/v1

License: (c) (i) This work is licensed under a Creative Commons Attribution 4.0 International License. Read Full License 


\section{Abstract}

Phytoextraction strategy by harvesting dead leaves provides non-stop phytoremediation and a great saving in disposal cost of hazardous plant residues. This strategy is entirely dependent upon the amount of cadmium (Cd) accumulated in dead leaves. However, it is unknown that whether the leaf $\mathrm{Cd}$ accumulation is associated with its senescence and how to regulate its $\mathrm{Cd}$ accumulation. This study showed that $\mathrm{Cd}$ was preferentially and consistently distributed to and accumulated in the senescent leaves with the new leaf emergence and the old leaf dieback under $75 \mu \mathrm{M}$ of Cd stress in tall fescue (Festuca arundinacea). Individual leaf monitoring from its emergence to senescence showed that $\mathrm{Cd}$ concentration increased exponentially with the leaf life cycle, while leaf biomass decreased gradually after $14 \mathrm{~d}$ of leaf emergence. The total amount of $\mathrm{Cd}$ accumulated in the leaf showed an exponential increase during leaf senescence, regardless of the leaf biomass loss. Our results demonstrated that leaf $\mathrm{Cd}$ accumulation was significantly associated with its senescence and the highest $\mathrm{Cd}$ accumulated in dead leaves could be contributed from the continuous $C d$ input during the leaf senescent process, indicating that further regulatory studies should be focused on the leaf senescence process to achieve higher $\mathrm{Cd}$ accumulation and phytoextraction efficiency by harvesting dead leaves.

\section{Introduction}

Cadmium (Cd) is one of the most hazardous heavy metals in the environment (Larison et al., 2000), which induced gene mutation and serious diseases such as cardiovascular disease (Cosselman et al., 2015) and many kinds of cancers, even at low concentrations (Koedrith et al., 2013). Phytoextraction is a green technology using plants to remove soil Cd pollution (Benavides et al., 2021). Phytoextraction efficiency is mainly dependent upon the amount of $\mathrm{Cd}$ accumulated in the harvesting organs of plants (Adamidis et al., 2017; Yuan et al., 2019).

Current phytoextraction technology is to remove soil Cd pollution by harvesting plant shoots enriched with Cd (Hu et al., 2016; Luo et al., 2016). Most of the hyperaccumulators are annual plant species (Rascio \& Navari-Izzo, 2011; Sterckeman et al., 2019), which need to be replanted in their growing season after each harvesting to restore the phytoextraction process (Bidar et al., 2009; Pogrzeba et al., 2018). There is a period between harvesting and replanting, in which soil erosion could lead to a risk of $\mathrm{Cd}$ diffusion (Wang et al., 2019; Kidd, et al., 2015). Besides, the huge amount of harvesting plant residues is difficult and costly for their disposal (Ghosh \& Singh, 2005; Carrier et al.,2011; Chaney \& Baklanov, 2017). Sas-Nowosielska et al. (2004) estimated that the cost of plant residue incineration was $180-220 € / \mathrm{t}$.

Our previous studies found that tall fescue (Festuca arundinacea) performed hypertolerance of soil Cd pollution by its avoidance mechanism (Xu \& Wang, 2003; Zuo et al., 2021). Most of the shoot Cd was accumulated in its senescent and dead leaves and little $\mathrm{Cd}$ was accumulated in its photosynthetic mesophyll tissues of the young and mature leaves (Dong et al., 2017; Fei et al., 2018). A novel strategy of Cd phytoextraction by harvesting the dead leaves was proposed because the dead leaves accumulated $73.4-87.2 \%$ of the shoot Cd with only $12.6-16.3 \%$ of the shoot biomass (Wang et al., 2019). This novel 
Cd phytoextraction strategy was also supported by Luo et al. $(2019 ; 2020)$, in which Cd phytoextraction by harvesting the senescent and dead leaves of tall fescue was enhanced by the intercropping with Cicer arietinum and irrigation of the magnetized water.

Compared with the previous phytoextraction technologies, this new strategy has obvious advantages in saving the disposal cost of the harvesting plant residues and providing continuous and uninterrupted soil phytoextraction. However, the phytoextraction strategy by harvesting the dead leaf is entirely dependent upon the capacity of $\mathrm{Cd}$ accumulation in dead leaves. Dead leaves are the result of leaf senescence. It is of vital importance to know whether the leaf $\mathrm{Cd}$ accumulation is associated with its senescence and what happened during the process of leaf senescence in tall fescue.

Therefore, this study was designed to investigate: (1) how leaf $\mathrm{Cd}$ accumulated during its senescent process, and (2) whether the higher Cd concentration in the senescent leaf was from external Cd input or its biomass loss.

\section{Materials And Methods}

\subsection{Plant growth and experiment design}

Tall fescue (Festuca arundinacea) cultivar 'jaguar 4G' was used in this study. One seed of tall fescue was placed in the filter paper saturated with distilled water and incubated in the dark at $25^{\circ} \mathrm{C}$. When the seed germinated and roots appeared from the filter paper at seven days, seedlings were transplanted into plastic tanks ( 25 seedlings per tank) containing $2.4 \mathrm{~L}$ of the half-strength Hoagland's solution. The growth condition was the same as our previous hydroponic experiments $\left(25 / 20 \pm 2^{\circ} \mathrm{C}\right.$ of day/night temperatures, $50 \pm 2 \%$ of relative humidity, $14 \mathrm{~h}$ of photoperiod, and $400 \mu \mathrm{mol} \mathrm{m} \mathrm{m}^{-2} \mathrm{~s}^{-1}$ of canopy photosynthetically active radiation).

A completely random design was used in this experiment with four replicates in each treatment. Half of the experimental tanks were exposed to $\mathrm{Cd}$ stress when the 4th leaf was emerging from the main shoot and the other half as the non-Cd control. Cd stress was at $75 \mu \mathrm{M} \mathrm{Cd}^{2+}$ concentration by adding $\mathrm{CdCl}_{2} \cdot 2.5 \mathrm{H}_{2} \mathrm{O}$ into the $1 / 2$ Hoagland's solution. The nutrient solution was maintained at $6.5 \mathrm{pH}$ and replaced freshly every week. All leaves grown from the plants were recorded and labeled throughout the whole experimental period. Plants were sampled every $7 \mathrm{~d}$ for the following measurements.

\subsection{Measurements}

Plant growth parameters: Plant height and root length of tall fescue were measured according to Zuo et al. (2021). Ten plants in each pot were selected randomly and their average was used as the treatment tank. Plant samples were separated into shoots and roots based on a single tiller, then oven-dried to a constant weight, and recorded as their biomasses. 
Cd analyses: Each leaf was separated and sampled for $\mathrm{Cd}$ analyses. To avoid the dead leaves from being contaminated by $\mathrm{Cd}$ in the nutrient solution, the bottom leaf was cut off before it drooped. Therefore, the leaves in this experiment were only defined as the emerging, mature, and senescent leaves and no dead leaves appeared. Cd analyses followed the procedures of our previous studies (Xu and Wang, 2013) and were determined using inductively coupled plasma spectroscopy (ICP Optima 8000, PerkinElmer, America). Quality control of the analyses was verified by co-analyzing certified reference samples for every 12 experimental samples. A blank was used to check interference and cross-contamination for every 15 samples. The Cd recovery rate was $95 \sim 103 \%$.

Data analysis was followed by the same method as previously described (Xu and Wang, 2014; Wang et al., 2017). Statistical analysis was performed by analysis of variance (ANOVA) with the software SAS (version 9.1, SAS Institute Inc., Cary, NC). Asterisk and the different letters in the figures indicate statistically significant differences separated by Ducan's multiple tests at a significant level of $p<0.05$.

\section{Results}

\subsection{Plant growth}

Cd stress significantly inhibited the plant growth of tall fescue (Fig. 1). Plant vertical growth was stopped by the $\mathrm{Cd}$ stress as indicated by no significant changes of plant height during the whole experimental period, which was significantly lower than the non-Cd control after $21 \mathrm{~d}$ of treatment (Fig. 1A). Shoot biomass per tiller was not as sensitive as plant height in response to the Cd stress and it still stably increased under the $\mathrm{Cd}$ stress until $49 \mathrm{~d}$ of treatment, which only showed significantly lower than the nonCd control after $28 \mathrm{~d}$ of treatment (Fig. 1B). Root length and root biomass per tiller also showed steady increases under the $\mathrm{Cd}$ stress until $28 \mathrm{~d}$ of treatment and only showed their decline after $49 \mathrm{~d}$ of treatment (Fig. 1C, D). When compared with the non-Cd control, root length was significantly shorter during the whole experimental period, but root biomass per tiller only showed a significantly lower after $21 \mathrm{~d}$ of treatment.

\section{$3.2 \mathrm{Cd}$ accumulation in roots and shoots}

Root accumulated a significantly higher $\mathrm{Cd}$ than shoot until $49 \mathrm{~d}$ after Cd stress (Fig. 2). Root Cd accumulation shows a sharp increase before the $35 \mathrm{~d}$ but remains at a relatively stable level after $42 \mathrm{~d}$ of Cd stress, which meet an equation: $y=-3.2+3.9 x-0.08 x^{2}+0.0006 x^{3}$, while $y$ : root $C d$ accumulation $\left(\mu \mathrm{g} /\right.$ plant); $x$ : days under the $\mathrm{Cd}$ stress. $\mathrm{R}^{2}=0.96 * \star(p<0.001)$. Shoot $\mathrm{Cd}$ accumulation shows a sharp increase throughout the whole experimental period, which meets an exponential curve: $y=6.0 e^{0.04 x}$, while $y$ : shoot Cd accumulation ( $\mu$ g/plant); $x$ : days under the Cd stress. $R^{2}=0.95 * \star(p<0.001)$. At $56 \mathrm{~d}$ of $\mathrm{Cd}$ stress, no significant difference in $\mathrm{Cd}$ accumulation was noticed between root and shoot.

\subsection{Cd distribution in different leaves}


The main shoot maintained $5 \sim 6$ living leaves during the experimental period, with one emerging leaf, one senescent leaf, and three mature leaves before $28 \mathrm{~d}$ or four mature leaves after $35 \mathrm{~d}$ of $\mathrm{Cd}$ stress. The first leaf showed senescent symptoms (yellowing) at $7 \mathrm{~d}$ and $14 \mathrm{~d}$ and completely dead before $21 \mathrm{~d}$ of $\mathrm{Cd}$ stress. As the young leaves continuously emerged from the top, the bottom leaf was gradually getting senescent. At $56 \mathrm{~d}$ of $\mathrm{Cd}$ stress, the 11th leaf was emerging, and the 6 th leaf was getting senescent. In all eight periodical samplings, $\mathrm{Cd}$ distribution among the leaves showed a consistent pattern with the highest $\mathrm{Cd}$ concentration in the senescent leaf, the lowest $\mathrm{Cd}$ in the emerging leaf, and gradually $\mathrm{Cd}$ increases with the lower leaf position among the mature leaves (Fig. 3).

\subsection{Cd accumulation with leaf development}

The higher $\mathrm{Cd}$ concentration in the senescent leaf could have resulted from the loss of leaf biomass during the process of leaf senescence or $\mathrm{Cd}$ preferential distribution and accumulation associated with leaf senescence. In our experiment, Leaf 4 (L4), 5 (L5), and 6 (L6) were continuously monitored for the changes of leaf biomass, $\mathrm{Cd}$ concentration, and accumulation from their emergence to senescence. The senescent symptom (yellowing) only occurred in $49 \mathrm{~d}$ after leaf emerging in all three leaves. In $14 \mathrm{~d}$ after emerging, leaf biomass increased with leaf emerging and development. However, leaf biomass decreased steadily after $21 \mathrm{~d}$ of emerging in all L4, L5, and L6, showing that leaf senescent started much earlier than its symptom appeared.

Cd concentrations in all three leaves showed the sharp increase with the leaf development and meet the exponential curve (Fig. 4). The leaf 4 (L4) was: $y=33.0 e^{0.05 x}, R^{2}=0.99 * \star(p<0.01)$. The leaf 5 (L5) was: $y=37.7 e^{0.04 x}, R^{2}=0.95 * \star(p<0.01)$. The leaf $6(L 6)$ was: $y=28.8 e^{0.06 x}, R^{2}=0.93 * \star(p<0.01)$, while $y: C d$ concentration $(\mathrm{mg} / \mathrm{kg})$ in the leaf; $x$ : days after its emergence.

Cd amount accumulated in all three leaves also showed the sharp increase with the leaf development and meet the exponential curve. The leaf 4 (L4) was: $y=0.6 e^{0.03 x}, R^{2}=0.75 *(p<0.05)$. The leaf $5(L 5)$ was: $y=0.75 e^{0.04 x}, R^{2}=0.87 * \star(p<0.01)$. The leaf 6 (L6) was: $y=1.0 e^{0.04 x}, R^{2}=0.87 * \star(p<0.01)$, while $y$ : Cd concentration $(\mathrm{mg} / \mathrm{kg})$ in the leaf; $x$ : days after its emergence.

A correlation analysis showed that leaf $\mathrm{Cd}$ accumulations were significantly increased during the leaf senescence process (after $21 \mathrm{~d}$ of leaf emerging) despite the decline of leaf biomass in all three monitored leaves (Fig. 5). The exponential curves to describe the relationships of leaf $\mathrm{Cd}$ accumulation and leaf biomass decline are: $\mathrm{y}=12.2 \mathrm{e}^{-0.1 \mathrm{x}}, \mathrm{R}^{2}=0.45 * *(p<0.01)$ for $\mathrm{L} 4, ; \mathrm{y}=8.1 \mathrm{e}^{-0.05 \mathrm{x}}, \mathrm{R}^{2}=0.61$ ** $(p<$ $0.01)$ for $L 5$, and $y=24.3 e^{-0.08 x}, R^{2}=0.79 * \star(p<0.01)$ for $L 6$, respectively.

\section{Discussion}

Tall fescue is a perennial turfgrass species that can provide soil phytoremediation for many years once it is established (Banuelos et al., 1996; Adamidis et al., 2017). The phytoextraction strategy by harvesting the dead leaves in tall fescue has many advantages over current phytoextraction methods: (1) It provides non-stop year-round phytoextraction. Harvesting the dead leaves does not affect the normal growth of tall 
fescue plants (Wang et al., 2019). (2) It does not need to harvest and replant after each phytoextraction cycle as the general phytoextraction did (Adamidis et al., 2017). The cost and labor for soil plowing, sowing or transplanting, seedling cultivation, harvesting, and replanting can be saved (Qu et al., 2013). (3) Great saving the disposal cost of the harmful plant residues harvested from the phytoextraction process. The dead leaves only accounted for $12.6 \sim 16.3 \%$ of the total shoot biomass (Wang et al., 2019), and 6.4 $\sim 11.6 \%$ of the total plant biomass (Luo et al., 2020). (4) The dead leaves of tall fescue can be harvested by a verti-cutter machine with increasing the blade thickness to $2 \mathrm{~mm}$ (Fig. S1). However, the phytoextraction efficiency of this novel technology depends entirely on the plant capacity of $\mathrm{Cd}$ distribution and accumulation into the dead leaves, which could be associated with its senescent process.

In this study, we demonstrated stability and consistency of Cd distribution and accumulation into the senescent leaf in tall fescue in the process of new leaves continuously emerging from the top and the lower leaves getting senescence throughout the experimental period (Fig. 3). Tall fescue maintained its normal growth under the $\mathrm{Cd}$ stress, which was indicated by the increase of shoot biomass and the stable $4 \sim 5$ green leaves per tiller (Fig. 1 and Fig. 3). The removal of dead leaves did not affect the normal plant growth, because new leaves emerged to compensate for the loss of dead leaves. Our results confirmed that the Cd phytoextraction strategy by harvesting the dead leaves could provide a non-stop phytoremediation for the Cd-contaminated soils.

Luo et al. reported that intercropped with Cicer arietinum (2019) and irrigated by magnetized water (2020) promoted Cd phytoextraction efficiency via increasing the biomass of dead leaves, but no significant changes in Cd concentrations were found in both the senescent and dead leaves. These results indicated that the Cd phytoextraction efficiency of harvesting the dead leaves could be further improved by regulatory methods to promote the leaf senescence and increase the biomass of the senescent and dead leaves. Our previous study showed that some chelating agents promoted $\mathrm{Cd}$ accumulated into the senescent and dead leaves without significant change of plant growth and leaf senescent process (Wang et al., 2019), indicating that the Cd phytoextraction efficiency of harvesting the dead leaves could be further improved by promoting the $\mathrm{Cd}$ accumulation during the process of leaf senescence.

Cd is transported from roots to aboveground shoots via xylem mass flow (Uraguchi et al., 2009; Song et al., 2017). The driving force of this long-distance transportation is transpirational pulling (Yingjajaval, 2013) and root pressure (Tao et al., 2017). Thus, the young and mature leaves with active transpiration received more nutrients from their long-distance xylem transportation (Broschat \& Elliott, 2004; Siebrecht et al., 2003). In most plant species, $\mathrm{Cd}$ is more likely to distribute and accumulate in the active young and mature leaves than in the senescent and dead leaves (Perronnet et al., 2003; Cao et al., 2014), which could be explained by the difference in transpirational pulling.

Most nutrients can be reused in plants, and they can be decomposed and transported out to the active plant parts for their reuse when the leaves get into senescence (Avila-Ospina et al., 2014; Maillard et al., 2015; Have et al., 2017). Most decomposed nutrients are transported and redistributed via the phloem 
pathway (Achat et al., 2018; Ding et al., 2019). Only a few non-reusable mineral nutrients cannot be transported out from the senescent leaves and resulted in a higher accumulation in the senescent leaves than that in the younger leaves (Chen et al., 2016; Shao et al., 2018).

Cd is very toxic to plant tissues (Choppala et al., 2014). Currently, no evidence showed that Cd could be redistributed and transported out when leaves get senescence (Ismael et al., 2019). The partition of transpiration flow could explain the higher $\mathrm{Cd}$ accumulation in the young and mature leaves via the xylem pathway in most plant species. Some previous studies reported that the older leaves accumulated double Cd concentrations than the younger leaves in Schinus molle (Pereira et al., 2017), Brassica juncea (Ru et al., 2004), and Brassica napus (Wang and Su, 2005). Their double Cd concentrations in the older leaves could be contributed by leaf biomass loss or $\mathrm{Cd}$ redistribution during the leaf senescent process. Mendoza-Cózatl et al. (2008) found that Cd could be transported as PC-Cd and GSH-Cd complexes via phloem from source to sink in Brassica napus. Fujimaki et al. (2010) also reported that Cd was transferred from the xylem to phloem in the basal nodes and then transported to the grains at the grainfilling stage in rice. Our previous study found that $\mathrm{Cd}$ fluorescence was only located in the xylem part of vascular bundles and no Cd fluorescence was observed in the phloem part of tall fescue (Dong et al., 2017), indicating that $\mathrm{Cd}$ accumulation in the leaf of tall fescue was a one-way process. Cd could be only pumped in via the xylem pathway, not redistributed out via the phloem pathway.

In tall fescue, the senescent and dead leaves accumulated over ten times of Cd concentration than that in the emerging leaves (Fei et al., 2018; Wang et al., 2019). In this paper, we found that both Cd concentration and amount were exponentially increased with the leaf aging, despite the decreases of the leaf biomass during the process of leaf senescence (Fig. 4). The exponential increases of leaf $\mathrm{Cd}$ amount in all three monitored leaves demonstrated that leaf $\mathrm{Cd}$ accumulation was significantly associated with its senescence process. Our data elucidated the dynamics of leaf $\mathrm{Cd}$ accumulation during its senescence in tall fescue. Leaf $\mathrm{Cd}$ was actively accumulated and the external $\mathrm{Cd}$ was continuously inputted to the senescent leaves during their senescent process, which well explained why the highest $\mathrm{Cd}$ accumulation was found in the dead leaves (Fei et al., 2018; Luo et al., 2019; Wang et al., 2019; Luo et al., 2020). Further researches should focus on the regulatory mechanism of $\mathrm{Cd}$ accumulation in the process of leaf senescence. Phytoextraction efficiency by harvesting dead leaves could achieve by encouraging more $\mathrm{Cd}$ input during leaf senescence and higher $\mathrm{Cd}$ accumulation in dead leaves in tall fescue.

\section{Conclusion}

The tall fescue plant maintained normal growth under $75 \mu \mathrm{M}$ of $\mathrm{Cd}$ stress. Cd was preferentially and consistently accumulated in the older leaves throughout the whole experimental period. Individual leaf monitoring showed that leaf $\mathrm{Cd}$ was exponentially increased during the leaf senescent process, despite the leaf biomass loss. Our results indicated that leaf $\mathrm{Cd}$ accumulation was significantly associated with the leaf senescence in tall fescue. The highest Cd accumulated in the dead leaves was contributed by the continuous $\mathrm{Cd}$ input during their senescent processes. These results provide insights into the relationship 
between $\mathrm{Cd}$ accumulation and leaf senescence and lay a foundation for the regulatory mechanism to improve the phytoextraction efficiency by harvesting dead leaves in tall fescue.

\section{Declarations}

Acknowledgement

This project was financially supported by the National Natural Science Foundation of China (Project Nos. 31872412).

Ethical Approval

Not applicable

Consent to Participate

Not applicable.

Consent to Publish

Not applicable.

Authors Contributions

Ling Fei: Investigation, Formal analysis, Writing - original draft. ShaoFan Zuo: Investigation, Formal analysis. JiaXin Zhang: Investigation, Formal analysis. ZhaoLong Wang: Conceptualization, Methodology, Supervision, Writing - review \& editing.

Funding

The authors wish to acknowledge the financial support of the National Natural Science Foundation of China (Project Nos. 31872412) for this research.

Competing Interests

The authors declare no competing interests.

Availability of data and materials

All data generated or analysed during this study are included in this published article.

\section{References}

Achat, D.L., Pousse, N., Nicolas, M., Augusto, L., 2018. Nutrient remobilization in tree foliage as affected by soil nutrients and leaf life span. Ecol. Monogr. 88, 408-428. DOI: 10.1002/ecm.1300 
Adamidis, G.C., Aloupi, M., Mastoras, P., Papadaki, M.I., Dimitrakopoulos, P.G., 2017. Is annual or perennial harvesting more efficient in Ni phytoextraction? Plant Soil 418, 205-218. DOI: 10.1007/s11104-017-32879

Avila-Ospina, L., Moison, M., Yoshimoto, K., Masclaux-Daubresse, C., 2014. Autophagy, plant senescence, and nutrient recycling. J. Exp. Bot. 65, 3799-3811. SI. DOI: 10.1093/jxb/eru039

Banuelos, G.S., Zayed, A., Terry, N., Wu, L., Akohoue, S., Zambrzuski, S., 1996. Accumulation of selenium by different plant species grown under increasing sodium and calcium chloride salinity. Plant Soil 183, 49-59. DOI:10.1007/BF02185564

Benavides, B.J., Drohan, P.J., Spargo, J.T., Maximova, S.N., Guiltinan, M.J., Miller, D.A., 2021. Cadmium phytoextraction by Helianthus annuus (sunflower), Brassica napus cv Wichita (rapeseed), and Chyrsopogon zizanioides (vetiver). Chemosphere 265: 129086. DOI:

10.1016/j.chemosphere.2020.129086

Bidar, G., Pruvot, C., Garcon, G., Verdin, A., Shirali, P., Douay, F., 2009. Seasonal and annual variations of metal uptake, bioaccumulation, and toxicity in Trifolium repens and Lolium perenne growing in a heavy metal-contaminated field. Environ. Sci. Pollut. Res. 16, 42-53. DOI: 10.1007/s11356-008-0021-4

Broschat, T.K., Elliott, M.L., 2004. Nutrient distribution and sampling for leaf analysis in St. Aaugustinegrass. Commun. Soil Sci. Plant Anal. 35, 2357-2367. DOI: 10.1081/LCSS-200030677

Cao, D., Zhang, H., Wang, Y., Zheng, L., 2014. Accumulation and distribution characteristics of zinc and cadmium in the hyperaccumulator plant Sedum plumbizincicola. Bull. Environ. Contam. Toxicol. 93 (2), 171-176. DOI: 10.1007/s00128-014-1284-8.

Carrier, M., Loppinet-Serani, A., Absalon, C., Marias, F., Aymonier, C., Mench, M., 2011. Conversion of fern (Pteris vittata L.) biomass from a phytoremediation trial in sub and supercritical water conditions. Biomass Bioenergy 35 (2), 872-883. DOI: 10.1016/j.biombioe.2010.11.007.

Chaney, R.L., Baklanov, I.A., 2017. Phytoremediation and phytomining: status and promise. In: Cuypers, A., Vagronsveld, J. (Eds.), Phytoremediation. Advances in Botanical Research 83, pp. 189-221. DOI: 10.1016/bs.abr.2016.12.006

Chen, Q.W., Mu, X.H., Chen, F.J., Yuan, L.X., Mi, G.H., 2016. Dynamic change of mineral nutrient content in different plant organs during the grain filling stage in maize grown under contrasting nitrogen supply. Eur. J. Agron. 80, 137-153. DOI: 10.1016/j.eja.2016.08.002

Choppala, G., Saifullah., Bolan, N., Bibi, S., Iqbal, M., Rengel, Z., Kunhikrishnan, A., Ashwath, N., Ok, Y.S., 2014. Cellular mechanisms in higher plants governing tolerance to cadmium toxicity. Crit. Rev. Plant Sci. 33, 374-391. DOI: 10.1080/07352689.2014.903747 
Cosselman, K.E., Navas-Acien, A., Kaufman, J.D., 2015. Environmental factors in cardiovascular disease. Nat. Rev. Cardiol. 12, 627-642. DOI: 10.1038/nrcardio.2015.152

Ding, G.D., Lei, G.J., Yamaji, N., Yokosho, K., Mitani-Ueno, N., Huang, S., Ma, J.F., 2019. Vascular cambiumlocalized AtSPDT mediates xylem-to-phloem transfer of phosphorus for its preferential distribution in Arabidopsis. Mol. Plant DOI:10.1016/j.molp.2019.10.002

Dong, Q., Xu, P.X., Wang, Z.L., 2017. Differential cadmium distribution and translocation in roots and shoots related to hyper-tolerance between tall fescue and Kentucky bluegrass. Front. Plant Sci. 8, 113. DOI: $10.3389 /$ fpls.2017.00113

Fei, L., Xu, P.X., Dong, Q., Mo, Q., Wang, Z.L., 2018. Young leaf protection from cadmium accumulation and regulation of nitrilotriacetic acid in tall fescue (Festuca arundinacea) and Kentucky bluegrass (Poa pratensis). Chemosphere 212, 124-132. DOI: 10.1016/j.chemosphere.2018.08.072

Fujimaki, S., Suzui, N., Ishioka, N.S., Kawachi, N., Ito, S., Chino, M., Nakamura, S., 2010. Tracing cadmium from culture to spikelet: Noninvasive imaging and quantitative characterization of absorption, transport, and accumulation of cadmium in an intact rice plant. Plant Physiol. 152, 1796-1806. DOI: 10.1104/pp.109.151035

Ghosh, M., Singh, S.P., 2005. A review on phytoremediation of heavy metals and utilization of its byproducts. Asian J. Energ. Environ. 6 (04), 214-231.

Have, M., Marmagne, A., Chardon, F., Masclaux-Daubresse, C., 2017. Nitrogen remobilization during leaf senescence: lessons from Arabidopsis to crops. J. Exp. Bot. 68, 2513-2529. SI. DOI: 10.1093/jxb/erw365

Hu, Y.N., Cheng, H.F., Tao, S., 2016. The challenges and solutions for cadmium-contaminated rice in China: A critical review. Envorn. Int. 92-93, 515-532. DOI: 10.1016/j.envint.2016.04.042

Ismael, M.A., Elyamine, A.M., Moussa, M.G., Cai, M.M., Zhao, X.H., Hu, C.X., 2019. Cadmium in plants: uptake, toxicity, and its interactions with selenium fertilizers. Metallomics 11, 255-277. DOI: $10.1039 / \mathrm{c} 8 \mathrm{mt} 00247 \mathrm{a}$

Kidd, P., Mench, M., Alvarez-Lopez, V., Bert, V., Dimitriou, I., Friesl-Hanl, W., Herzig, R., Janssen, J.O., Kolbas, A., Muller, I., Neu, S., Renella, G., Ruttens, A., Vangronsveld, J., Puschenreiter, M., 2015. Agronomic practices for improving gentle remediation of trace element-contaminated soils. Int. J. Phytoremediation 17, 1005-1037. DOI: 10.1080/15226514.2014.1003788

Larison, J.R., Likens, G.E., Fitzpatrick, J.W., Crock, J.G., 2000. Cadmium toxicity among wildlife in the Colorado Rocky Mountains. Nature. 406, 6792, 181-183. DOI: 10.1038/35018068

Luo, J., He, W.X.,; Rinklebe, J., Igalavithana, A.D., Tack, F.M.G., Ok, Y.S., 2019. Distribution characteristics of $\mathrm{Cd}$ in different types of leaves of Festuca arundinacea intercropped with Cicer arietinum L.: A new 
strategy to remove pollutants by harvesting senescent and dead leaves. Environ. Res. 179, 108801. DOI: 10.1016/j.envres.2019.108801

Luo, J., He, W.X., Qi, S.H., Wu, J., Gu, X.W.S., 2020. A novel phytoremediation method assisted by magnetized water to decontaminate soil $\mathrm{Cd}$ based on harvesting senescent and dead leaves of Festuca arundinacea. J. Hazard. Mater. 383, 121115. DOI: 10.1016/j.jhazmat.2019.121115

Luo, J., Qi, S.H., Gu, X.W.S., Wang, J.J., Xie, X.M., 2016. Evaluation of the phytoremediation effect and environmental risk in remediation processes under different cultivation systems. J. Clean. Prod. 119, 2531. DOI: 10.1016/j.jclepro.2016.01.043

Maillard, A., Diquelou, S., Billard, V., Laine, P., Garnica, M., Prudent, M., Garcia-Mina, J.M., Yvin, J.C., Ourry, A., 2015. Leaf mineral nutrient remobilization during leaf senescence and modulation by nutrient deficiency. Front. Plant Sci. 6, 317. DOI: 10.3389/fpls.2015.00317

Mendoza-Cozatl, D.G., Butko, E., Springer, F., Torpey, J.W., Komives, E.A., Kehr, J., Schroeder, J.I., 2008. Identification of high levels of phytochelatins, glutathione and cadmium in the phloem sap of Brassica napus. A role for thiol-peptides in the long-distance transport of cadmium and the effect of cadmium on iron translocation. Plant J. 54, 249-259. DOI: 10.1111/j.1365-313X.2008.03410.x

Pereira, M.P., Correa, F.F., de Castro, E.M., de Oliveira, J.P.V., Pereira, F.J., 2017. Leaf ontogeny of Schinus molle L. plants under cadmium contamination: the meristematic origin of leaf structural changes. Protoplasma 254, 2117-2126. DOI: 10.1007/s00709-017-1103-2

Perronnet, K., Schwartz, C., Morel, J.L., 2003. Distribution of cadmium and zinc in the hyperaccumulator Thlaspi caerulescens grown on multicontaminated soil - distribution of metals in Thlaspi caerulescens. Plant Soil 249 (1), 19-25. DOI: 10.1023/A:1022560711597.

Pogrzeba, M., Rusinowski, S., Krzyzak, J., 2018. Macroelements and heavy metals content in energy crops cultivated on contaminated soil under different fertilization-case studies on autumn harvest. Environ. Sci. Pollut. Res. 25, 2096-12106. SI. DOI: 10.1007/s11356-018-1490-8

Qu, G., Tong, Y., Gao, P., Zhao, Z., Song, X., Ji, P., 2013. Phytoremediation potential of Solanum nigrum L. under different cultivation protocols. Bull. Environ. Contam. Toxicol. 91, 306-309. DOI: 10.1007/s00128013-1046-z

Rascio, N., Navari-Izzo, F., 2011. Heavy metal hyperaccumulating plants: How and why do they do it? And what makes them so interesting? Plant Sci. 180, 169-181. DOI: 10.1016/j.plantsci.2010.08.016.

Ru, S.H., Wang, J.Q., Su, D.C., 2004. Characteristics of Cd uptake and accumulation in two Cd accumulator oilseed rape species. J. Environ. Sci. 16, 594-598.

Sas-Nowosielska, A., Kucharski, R., Malkowski, E., Pogrzeba, M., Kuperberg, J.M., Krynski, K., 2004. Phytoextraction crop disposal - an unsolved problem. Environ. Pollut. 128(3), 373-379. DOI: 
10.1016/j.envpol.2003.09.012.

Shao, J.F., Yamaji, N., Liu, X.W., Yokosho, K., Shen, R.F., Ma, J.F., 2018. Preferential distribution of boron to developing tissues is mediated by the intrinsic protein OsNIP3. Plant Physiol. 176, 1739-1750. DOI: 10.1104/pp.17.01641

Siebrecht, S., Herdel, K., Schurr, U., Tischner, R., 2003. Nutrient translocation in the xylem of poplar diurnal variations and spatial distribution along the shoot axis. Planta 217, 783-793. DOI:

$10.1007 / \mathrm{s} 00425-003-1041-4$

Song, Y., Jin, L., Wang, X.J., 2017. Cadmium absorption and transportation pathways in plants. Int. J. Phytoremediation 19, 133-141. DOI: 10.1080/15226514.2016.1207598

Sterckeman, T., Gossiaux, L., Guimont, S., Sirguey, C., 2019. How could phytoextraction reduce Cd content in soils under annual crops? Simulations in the French context. Sci. Total Environ. 654, 751-762. DOI: 10.1016/j.scitotenv.2018.11.173

Tao, Q., Jupa, R., Luo, J.P., Lux, A., Kovac, J., Wen, Y., Zhou, Y.M., Jan, J., Liang, Y.C., Li, T.Q., 2017. The apoplasmic pathway via the root apex and lateral roots contributes to Cd hyperaccumulation in the hyperaccumulator Sedum alfredii. J. Exp. Bot. 68, 739-751. DOI: 10.1093/jxb/erw453

Uraguchi, S., Mori, S., Kuramata, M., Kawasaki, A., Arao, T., Ishikawa, S., 2009. Root-to-shoot Cd translocation via the xylem is the major process determining shoot and grain cadmium accumulation in rice. J. Exp. Bot. 60, 2677-2688. DOI: 10.1093/jxb/erp119

Vines, P.L., Allen, T.W., DuBien, J., Stewart, B.R., Tomaso-Peterson, M., 2017. Ultradwarf bermudagrass performance as influenced by cultivar selection and cultural management practice. Crop Sci. 57, 497-505. DOI: $10.2135 /$ cropsci2016.05.0312

Wang, J.Q., Su, D.C., 2005. Distribution of cadmium in oilseed rape and Indian mustard grown on cadmium contaminated soil. J. Environ. Sci. 17, 572-575.

Wang, L.W., Hou, D.Y., Shen, Z.T., Zhu, J., Jia, X.Y., Ok, Y.S., Tack, F.M.G., Rinklebe, J., 2019. Field trials of phytomining and phytoremediation: A critical review of influencing factors and effects of additives. Crit. Rew. Environ. Sci. Technol. 1547-6537 (Online). DOI: 10.1080/10643389.2019.1705724

Wang, S.T., Dong, Q., Wang, Z.L., 2017. Differential effects of citric acid on cadmium uptake and accumulation between tall fescue and Kentucky bluegrass. Ecotox. Environ. Safe. 145, 200-206. DOI: 10.1016/j.ecoenv.2017.07.034

Wang, Y., Meng, D.P., Fei, L., Dong, Q., Wang, Z.L., 2019. A novel phytoextraction strategy based on harvesting the dead leaves: Cadmium distribution and chelator regulations among leaves of tall fescue. Sci. Total Enviorn. 650, 3041-3047. DOI: 10.1016/j.scitotenv.2018.10.072 
Xu P.X., Wang, Z.L., 2013. Physiological mechanism of hypertolerance of cadmium in Kentucky bluegrass and tall fescue: Chemical forms and tissue distribution. Environ. Exp. Bot, 96, 35-42. DOI: 10.1016/j.envexpbot.2013.09.001

Xu, P.X., Wang, Z.L., 2014. A comparison study in cadmium tolerance and accumulation in two coolseason turfgrasses and Solanum nigrum L. Water Air Soil Pollut. 225, 1938. DOI: 10.1007/s11270-0141938-5

Yingjajaval, S., 2013. Transpiration: Venue for nutrients delivery. VII International Symposium on Mineral Nutrition of Fruit Crops. in Poovarodom, S., and Yingjajaval, S., Ed. Acta Horticulturae 984, 25-35.

Yuan, X.Z., Xiong, T., Yao, S., Liu, C., Yin, Y.N., Li, H.C., Li, N.S., 2019. A real filed phytoremediation of multimetals contaminated soils by selected hybrid sweet sorghum with high biomass and high accumulation ability. Chemosphere 237, UNSP 124536. DOI: 10.1016/j.chemosphere.2019.124536

Zuo, S.F., Hu, S., Rao, J.L., Dong, Q., Wang, Z.L., 2021. Zinc promotes cadmium leaf excretion and translocation in tall fescue (Festuca arundinacea). Chemosphere 276, 130186. DOI:

10.1016/j.chemosphere.2021.130186

\section{Figures}



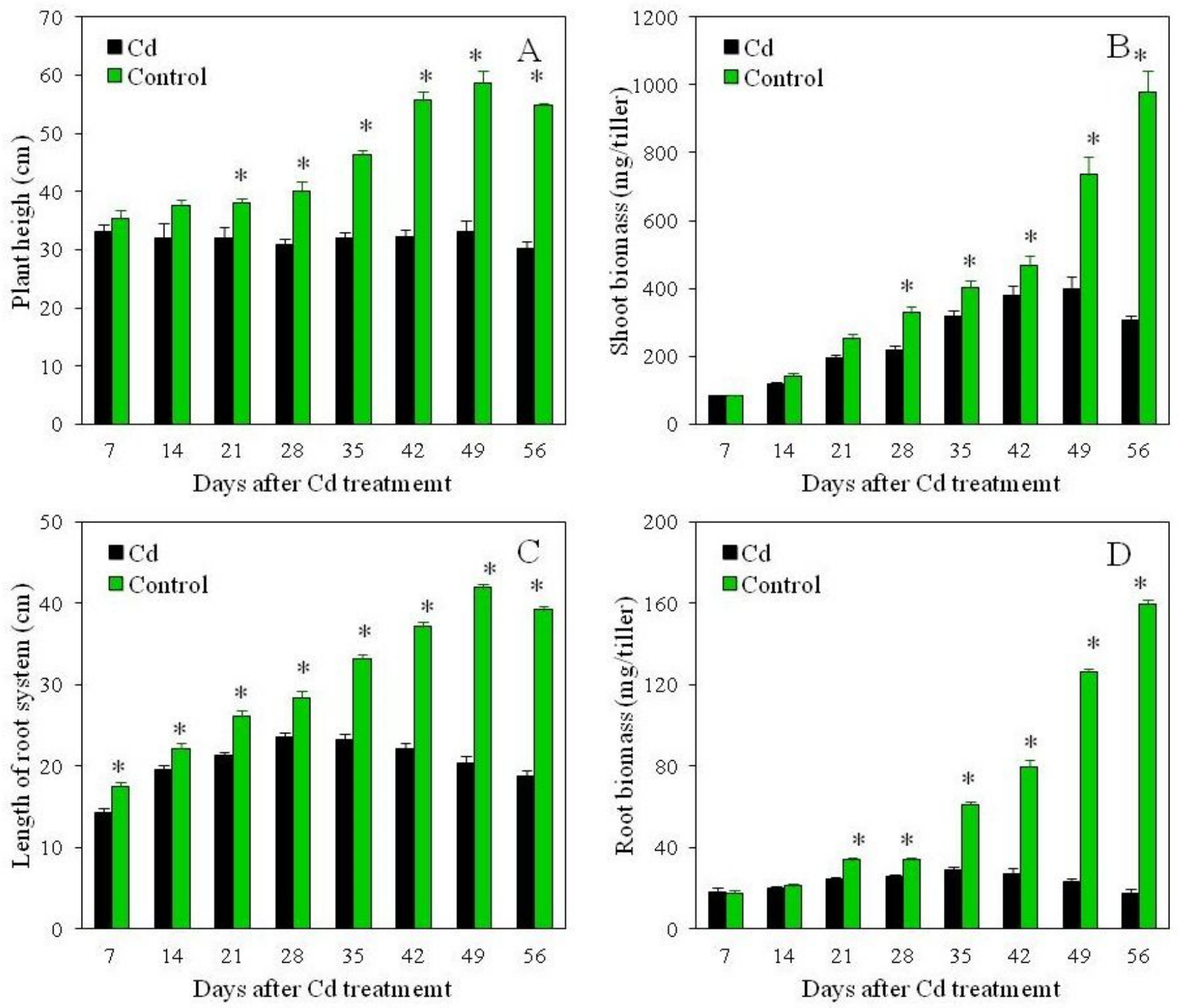

Figure 1

Plant growth in response to Cd stress. * represents the significant differences between $\mathrm{Cd}$ treatment and the control (LSD 0.05). A: plant height; B: Shoot biomass; C: Length of root system; D: Root biomass. 


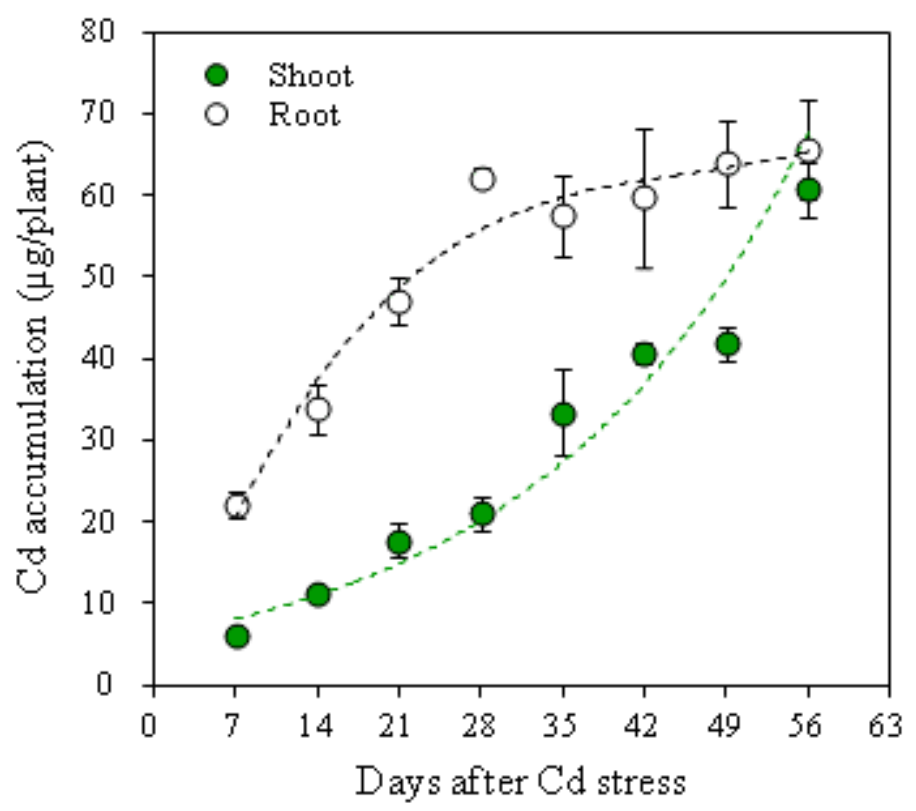

Figure 2

Dynamic of $\mathrm{Cd}$ accumulations in shoots and roots under the $\mathrm{Cd}$ stress. Shoot $\mathrm{Cd}$ accumulation shows a sharp increase which meet a exponential curve: $y=6.0 \mathrm{e} 0.04 \mathrm{x}$, while $\mathrm{y}$ : shoot Cd accumulation ( $\mu \mathrm{g} / \mathrm{plant})$; $x$ : days under the $C d$ stress. $R 2=0.95 * \star(p<0.01)$. Root $C d$ accumulation shows a sharp increase before the $35 \mathrm{~d}$ but remains at relatively stable level after $42 \mathrm{~d}$ of Cd stress, which meet a equation: $y=-3.2+$ $3.9 x-0.08 \times 2+0.0006 \times 3$, while $y$ : root $C d$ accumulation $(\mu \mathrm{g} /$ plant $) ; x$ : days under the $C d$ stress. $R 2=0.96$ $\star *(p<0.01)$. 

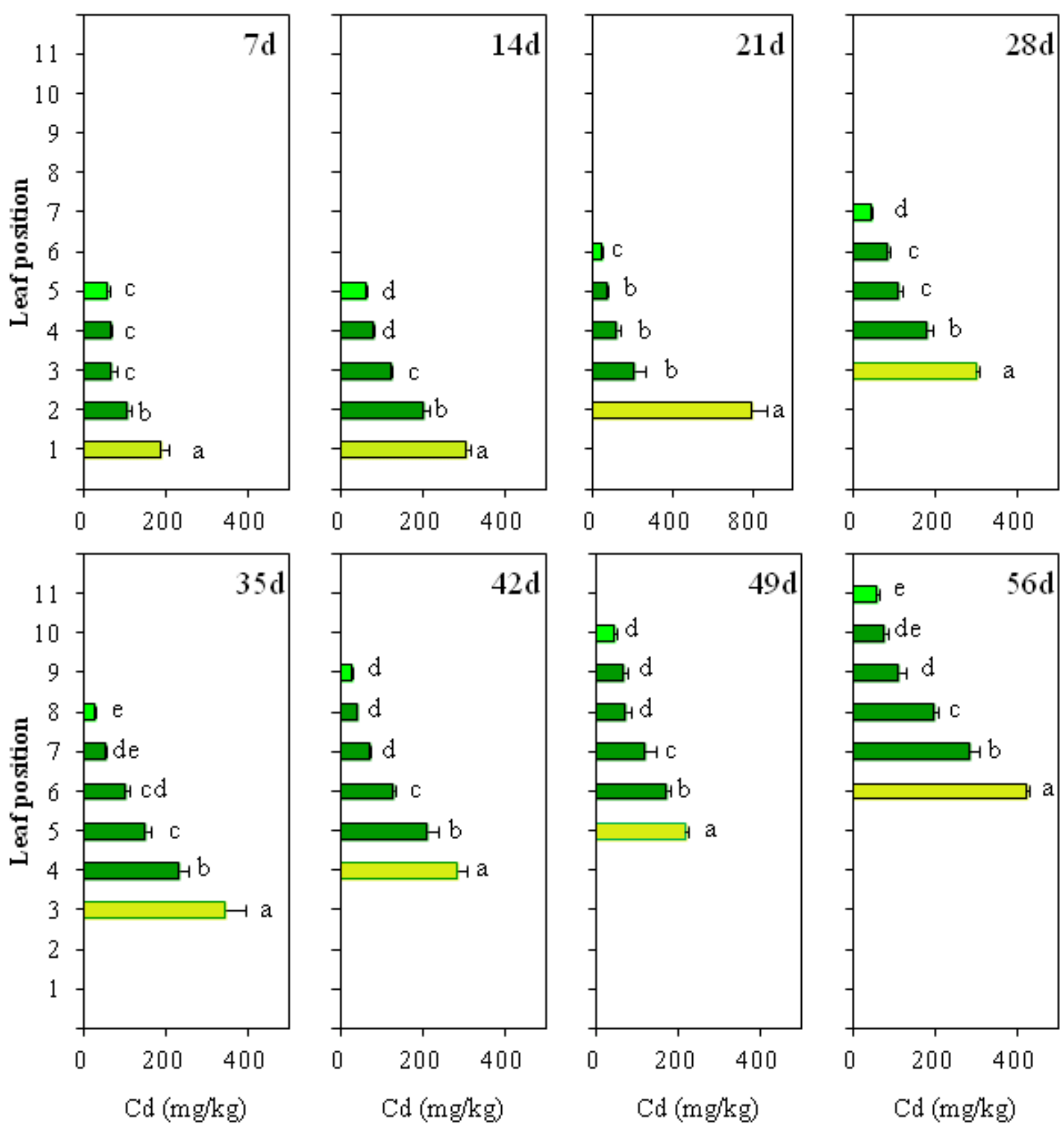

Figure 3

Cadmium concentrations in the different leaves after 7d, 14d, 21d, 28d, 35d, 42d, 49d, and 56d of the Cd stress. Leaf position refers to the position of leaves on the main stem from the base. $\mathbf{\square}$ : the emerging leaf; $\boldsymbol{\square}$ : the mature leaf; $\boldsymbol{\square}$ : the senescent leaf. Different low case letters represent the significant differences among the leaf positions (LSD 0.05). 

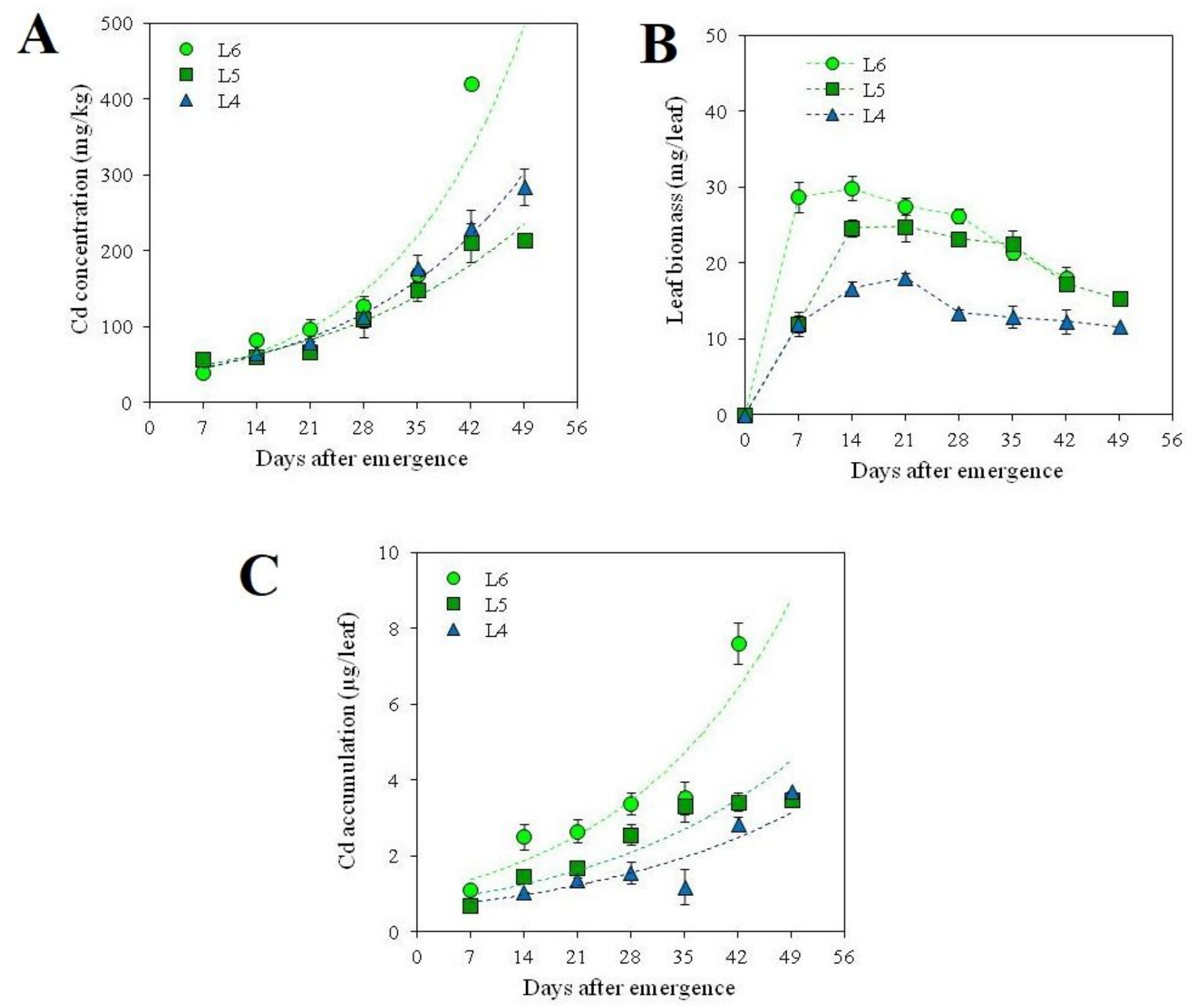

\section{Figure 4}

Leaf Cd accumulation during its development under the Cd stress. L4, L5, L6 are the 4, 5, and 6 leaves that emerged from the main stem of tall fescue (from the base). A: Leaf Cd concentration changes after its emergence. Cd concentrations in all three leaves showed the sharp increase with the leaf development and meet the exponential curve. The leaf 4 (L4) was: $y=33.0$ e0.05x, R2 $=0.99 * *(p<0.01, n=24)$. The leaf 5 (L5) was: $y=37.7$ e0.04x, R2 $=0.95 * \star(p<0.01, n=24)$. The leaf 6 (L6) was: $y=28.8$ e0.06x, R2 = $0.93 * \star(p<0.01, n=24)$, while $y$ : Cd concentration $(\mathrm{mg} / \mathrm{kg})$ in the leaf; $x$ : days after its emergence. $B$ : Leaf biomass changes after its emergence. C: Leaf $\mathrm{Cd}$ accumulation changes after its emergence. $\mathrm{Cd}$ accumulations in all three leaves showed the sharp increase with the leaf development and meet the exponential curve. The leaf 4 (L4) was: $y=0.6$ e0.03x, $R 2=0.75 *(p<0.05, n=24)$. The leaf 5 (L5) was: $y$ 
$=0.75 \mathrm{e} 0.04 x, R 2=0.87 * \star(p<0.01, n=24)$. The leaf $6(L 6)$ was: $y=1.0$ e0.04x, R2 $=0.87 * \star(p<0.01$, $\mathrm{n}=24)$, while $y$ : $\mathrm{Cd}$ concentration $(\mathrm{mg} / \mathrm{kg})$ in the leaf; $\mathrm{x}$ : days after its emergence.

A

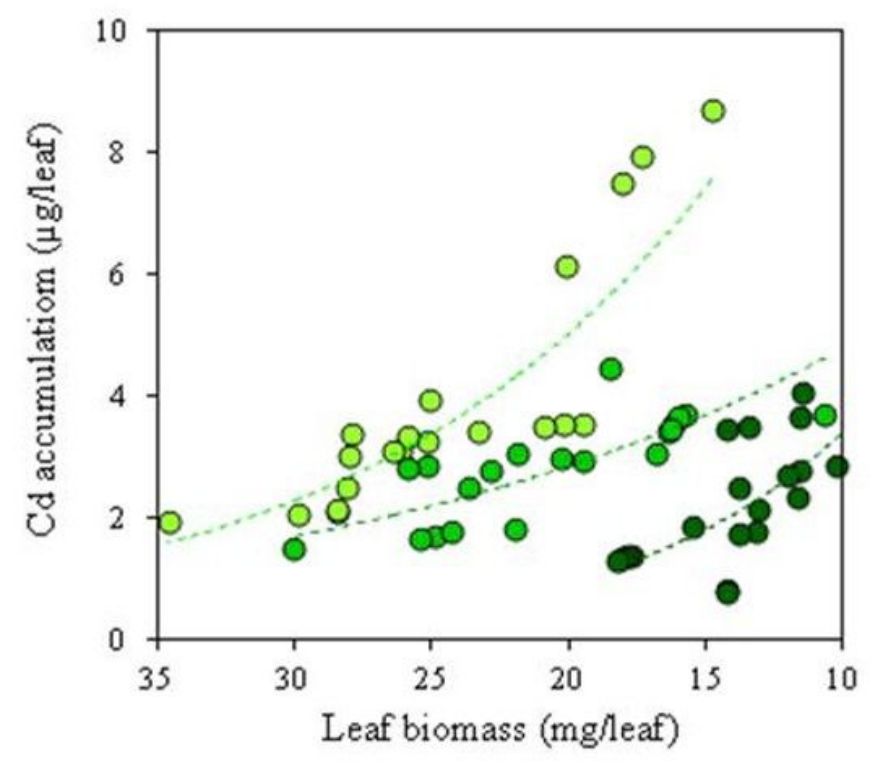

$\bullet$ Leaf $4 \bullet$ Leaf $5 \bullet$ Leaf 6
$\mathrm{B}$

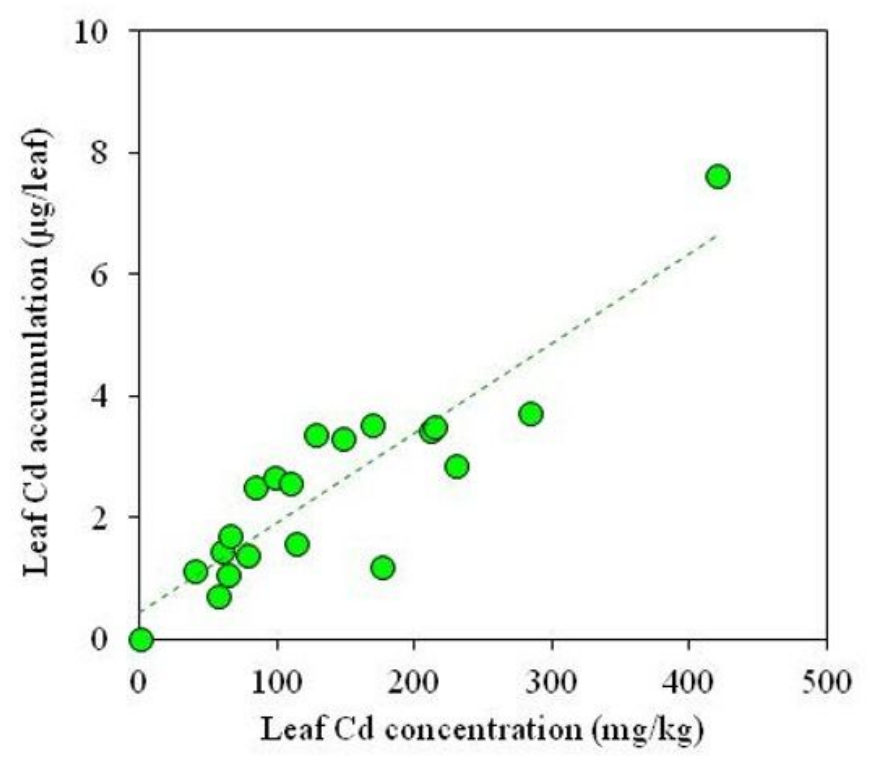

\section{Figure 5}

Leaf $\mathrm{Cd}$ accumulations associated with leaf senescence (biomass decline) under the Cd stress. L4, L5, L6 are the 4, 5, and 6 leaves that emerged from the main stem of tall fescue (from the base). A: Leaf Cd accumulations sharply increased associated with the leaf biomass decline and meet the exponential curve in all three leaves. 0 : Leaf 4: $\mathrm{Cd}$ accumulation increase associated with the leaf biomass decline can be described as: $y=12.2 \mathrm{e}-0.1 \mathrm{x}, \mathrm{R} 2=0.45 * \star(p<0.01, \mathrm{n}=20)$; $\mathbf{0}$ : Leaf 5 : Cd accumulation increase associated with the leaf biomass decline can be described as: $y=8.1$ e- $0.05 x, R 2=0.61$ ** $(p<0.01$, $n=20)$; : Leaf 6: Cd accumulation increase associated with the leaf biomass decline can be described as: $y=24.3 e-0.08 x, R 2=0.79 * *(p<0.01, n=20)$. B囚The linear relationship between leaf $C d$ concentraction and amount of leaf accumulation can be described as: $y=0.015 x+0.43, R 2=0.79 * *(p<$ $0.01, n=20)$.

\section{Supplementary Files}

This is a list of supplementary files associated with this preprint. Click to download.

- Supplementary20210719.docx 